\title{
Association of a single nucleotide polymorphism in the SUR1 gene with type 2 diabetes and obesity in Turkish patients
}

\section{Türk Toplumunda Tip 2 Diyabet'in ve Obezitenin, SUR1 genindeki tek nükleotit polimorfizmi ile birlikteliği}

\author{
Osman Evliyaoglu1 ${ }^{1}$, Enver Sancaktar ${ }^{2}$, Erkan Söğüit ${ }^{3}$, Mustafa Kemal Başaralı ${ }^{4}$, Nuriye Uzuncan ${ }^{1}$, \\ Baysal Karaca ${ }^{1}$
}

\author{
${ }^{1}$ Bozyaka Training and Research Hospital, Dept. of Clinical Biochemistry, Izmir, Turkey \\ ${ }^{2}$ Akdağmadeni State Hospital, Central Laboratory, Yozgat, Turkey \\ ${ }^{3}$ Gaziosmanpaşa University, Medical Faculty, Dept. of Medical Biochemistry,Tokat, Turkey \\ ${ }^{4}$ Dicle University, Medical Faculty, Dept. of Medical Biochemistry, Diyarbakır, Turkey
}

\begin{abstract}
Objectives: Sulfonylurea receptor 1 (SUR1) gene codes the SUR1 protein that plays a key role in glucose-induced insulin secretion. In this study, we have investigated the relationship between the polymorphism in exon 31 of the SUR1 gene and type 2 diabetes, and its association with obesity in Turkish diabetic patients.
\end{abstract}

Materials and methods: 90 patients (45 males and 45 females, aged 43-70 years old) who were followed up in the diabetes outpatient clinic were enrolled in the study. Serum glucose, triglyceride, cholesterol and blood HbAlc levels were determined. The SNPs in exon 31 were examined by a polymerase chain reaction/restriction fragment length polymorphism (PCR-RFLP) method.

Results: A significant increase in the frequency of the $A$ allele was observed in type 2 diabetic patients compared with that of the control group ( $41 \%$ vs. $24 \%, p<0.01)$, and this association was stronger in the subgroup of patients with obesity (A allele 44\%, $p<0.01$ ). There was a significant difference in genotype distribution of exon 31 R1273R SNP between the patients and controls $(P=0.01)$, especially between the patients with obesity and the control group $(P=0.007)$.

Conclusion: This study reports that the SNP in exon 31 of the SUR1 gene is strongly associated with type 2 diabetes mellitus in Turkish patients with concomitant obesity, suggesting interactions of SUR1 variants with type 2 diabetes and obesity. J Clin Exp Invest 2011;2(2):161-7

Key words: Type 2 diabetes, obesity, SUR1 gene polymorphism, RFLP

\section{ÖZET}

Amaç: Sulfonylurea receptor 1 (SUR1) geni SUR1 proteinini kodlayarak glukozla indüklenen insülin sekresyonunda anahtar rolü oynar. Bu çalışmanın amacı, SUR1 geninin 31. ekzonundaki polimorfizm ile Tip 2 diyabet arasındaki ilişkiyi ve diyabetik hastalardaki obezite ile beraberliğini araştırmaktır.

Gereç ve yöntem: Diyabet polikliniğinde takip edilen 90 hasta (45 kadın, 45 erkek ) çalışmaya dahil edildi. Serumda glukoz, trigliserid, kolesterol ve tam kanda HbAlc değerleri belirlendi. 31. Egzondaki SNP'ler ise polymeraz zincir reaksiyon / restriksiyon fragment uzunluk polymorphism (PCR-RFLP) yöntemiyle belirlendi.

Bulgular: Kontrol grubu ile karşılaştırıldığında Tip 2 diyabetik hastalarda A allel frekansının artmış olduğu gözlendi (\%41 ve \%24, p<0.01), ve bu ilişkinin obez alt grupta daha belirgin olduğu gözlendi (A allele \%44, p<0.01). Hasta ve kontrol grubu arasında 31. Ekzonun R1273R tek nükleotit polimorfiziminde genotip dağılımında obez alt grupta daha fazla olmak üzere $(p=0.007)$ anlamlı fark bulundu $(p=0.01)$.

Sonuç: SUR1 geninin 31. Ekzonundaki tek nükleotit polimorfizminin Türk tip 2 diyabet hastalarında ve obez alt grupta önemli rol aldığı söylenebilir. Klin Deney Ar Derg 2011;2(2):161-7

Anahtar kelimeler: Tip 2 diyabet, obezite, SUR1 gen polimorfizmi, RFLP

Yazışma Adresi /Correspondence: Dr. Osman Evliyaoglu,

Dicle Üniversitesi Merkez Laboratuvarı, Tıp Fakültesi, Diyarbakır, Turkey Email: oevliya@hotmail.com, Geliş Tarihi / Received: 07.03.2011, Kabul Tarihi / Accepted: 27.04.2011

Copyright (C) Klinik ve Deneysel Araştırmalar Dergisi 2011, Her hakkı saklıdır / All rights reserved 


\section{INTRODUCTION}

Diabetes mellitus (DM) is a metabolic disease caused by the absence of insulin or insulin resistance that results in impaired insulin action characterized with hyperglycemia. ${ }^{1}$ Thereby, the mechanism of insulin secretion comes into prominence to clarify the etiology of DM. Adenosine triphosphate (ATP)-sensitive potassium (KATP) channels in pancreatic B-cells which are activated by glucose, regulate insulin secretion. In these cells, the increase in intracellular ATP concentration as a result of glucose metabolism leads to closure of KATP channels. Closure of channels is followed by membrane depolarization, opening of voltage gated $\mathrm{Ca}^{2+}$ channels, intracellular $\mathrm{Ca}^{2+}$ flow and insulin exocytosis. ${ }^{2}$ The KATP channels comprise two proteins: a pore forming Kir6.2 and a regulatory subunit, namely the SUR1 as an ATP sensor. ${ }^{3}$ The genes encoding these two subunits are located $4.5 \mathrm{~kb}$ apart on the human chromosome $11 \mathrm{p} 15.1 .^{4}$

It has previously been shown in newborns that the mutation in the genes encoding these two proteins results in alterations of insulin secretion. ${ }^{5}$ Type 2 diabetes is a multifactorial disease that combines hereditary and environmental factors. ${ }^{6}$ It is also thought to be a polygenic disorder; that is, several defective genes are involved in the process. ${ }^{7}$ When the genes encoding the steps of the insulin secretion were investigated, a correlation was found between SNPs in the SUR1 gene and type 2 DM in different populations. ${ }^{8,10}$ However, even there is no threshold value for phenotypic differences; there is a firm correlation between insulin response to oral glucose load in nondiabetic subjects and the SNP which is located in exon 31 of the SUR1 gene ${ }^{11}$ The presence of the SNP at the same location in type $2 \mathrm{DM}$ has brought about the need to make similar studies in different communities. ${ }^{12}$

In this study, we investigated the presence of a similar SNP of the SUR1 gene in our community and its relationship with type $2 \mathrm{DM}$. We also investigated the association of this SNP with obesity in type 2 diabetic patients, based on the fact that obesity is common in type 2 diabetes that make us wonder about a possible intersection of genetic predispositions caused by polymorphisms in metabolic or regulatory genes.

\section{MATERIALS AND METHODS}

\section{Subjects}

The subjects were selected from Izmir, the third biggest city in Turkey which reflects the ethnical properties of the west of Turkey. 90 patients (45 males and 45 females, aged 43-70 years old) who were followed up in the diabetes outpatient clinic were enrolled in the study. The patients were diagnosed according to the American Diabetes Association (ADA) criteria. And, the patients given lipid-lowering therapy during the last six months, and have any disease that could affect lipid levels, were excluded from the study. Totally 80 age and sex matched healthy volunteers (39 males and 41 females, aged 45-70 years old) who did not have a family history of diabetes were included in the study as a control group after ruling out diseases which could diagnosed clinically and biochemically. Informed consent was obtained from each subject before participation.

\section{Samples}

Blood samples were drawn into vacutainer tubes between 08:00-09:30 am after 12 hours fasting. For serum separation, the blood samples were collected in gel-containing tubes and then centrifuged at 5000 rpm for 10 minutes and all samples were stored at $-20^{\circ} \mathrm{C}$ until analysis. For whole blood, we used the tubes with EDTA, and lithium heparin to prevent coagulation. Obtained DNAs were studied immediately by molecular methods.

\section{Biochemical parameters}

Glucose, triglyceride and cholesterol levels were spectrophotometrically assayed with Olympus AU5200 (Tokyo, Japan). HbA1c was measured by turbidimetric method with Technicon RA-XT autoanalyzer (Technicon Corp., New York, USA).

\section{DNA extraction}

Genomic DNA was extracted from peripheral blood samples by standard procedures. G'NOME DNA isolation kit (BIO 101, Joshua Way, CA, USA) was used. The method to detect the SNP in blood derived DNA was completely the same as previously described (Reis et al., 2000). The SNPs in exons 31 were examined by a polymerase chain reaction/ restriction fragment length polymorphism (PCRRFLP) based method in which the exons were num- 
bered starting from the 3' end instead of the 5' end of the SUR1 gene. The SNP in exon 31 was examined by PCR-RFLP with primers 5'-gtagaacagggtcetgtggc- 3'(forward) and 5'-tgtctccagtgacgaaggtg-3' (reverse). PCR conditions were: an initial denaturation at $95^{\circ} \mathrm{C}$ for $5 \mathrm{~min}$ and 30 cycles at $95^{\circ} \mathrm{C}$ for denaturation, $60^{\circ} \mathrm{C}$ for annealing, and $72^{\circ} \mathrm{C}$ for extension, each step lasting $45 \mathrm{~s}$, with a final extension for $7 \mathrm{~min}$ at $72^{\circ} \mathrm{C}$. Amplification yielded a $250-\mathrm{bp}$ fragment that, for the $\mathrm{G}$ allele, contained three BsiI restriction sites at base pairs 53, 118, and 119 from the 5 ' end of the forward primer. The sequence variation in the A allele abolished the consecutive Bsll sites at positions 118 and 119. PCR products were subjected to enzymatic digestion with BsII (New England Biolabs) and resolved on 2.0\% agarose gel electrophoresis. These genotyping patterns were confirmed by sequencing the DNA extracted from the gel bands of two carriers of each genotype (GG, GA, and AA).

\section{Statistical analysis}

Student's t-test was used to compare quantitative data between the DM and the control groups. Genotype and allelic frequencies among the groups of the study were compared by Chi-Square test. Subjects were compared according to their SUR1 genotype for differences in clinical and biochemical data by Kruskal-Wallis test and Mann-Whitney's test. ChiSquare test was performed in the analysis of associations between classified variables. All analyses were performed using the SPSS version 13.0 software. $\mathrm{P}$ values of $<0.05$ were considered to be statistically significant.

\section{RESULTS}

The clinical and biochemical characteristics of the study subjects are shown in Table 1. There was no statistically significant difference between the DM and the control groups for age and gender. The PCR product was $250 \mathrm{bp}$ in length. For the $\mathrm{G}$ allele, 250 bp fragment contained three Bsll restriction sites and, after digestion, generated fragment sizes of 132 bp, 65 bp, 52 bp and 1 bp (not seen on the gel) (Figure 1). The sequence variation in the A allele cancelled the consecutive Bsll sites at base pairs 118 and 119. Therefore, the A allele presented a pattern of 198 and $52 \mathrm{bp}$. Genotype and allele frequency distribution of exon 31 SNP of the SUR1 gene in diabetic patients and controls are shown in Table 2. A significantly higher frequency of the A allele was found in type $2 \mathrm{DM}$ patients compared with that of the control group ( $41 \%$ vs. $\left.24 \%, \chi^{2}=10.8, \mathrm{P}<0.01\right)$, and this association was stronger in the subgroup of patients with obesity (A allele $44 \%, \chi^{2}=11.5$, $\mathrm{P}<0.01)$.

The AA genotype $(21 \%$ vs. $7.5 \%, \mathrm{P}=0.01)$ and the combined $\mathrm{AA} / \mathrm{AG}$ genotypes $(60 \%$ vs. $40 \%$, $\mathrm{P}=0.009)$ were more prevalent in diabetic than in control subjects. In addition, this tendency was also observed in patients with obesity (AA 24\%, $\mathrm{P}=0.007$, and $\mathrm{AA} / \mathrm{AG} 64 \%, \mathrm{P}=0.015$ compared with controls), but no significant difference was found between non-obese patients and controls (AA 18\%, $\mathrm{P}=0.12$, and $\mathrm{AA} / \mathrm{AG} 56 \%, \mathrm{P}=0.13$ ).

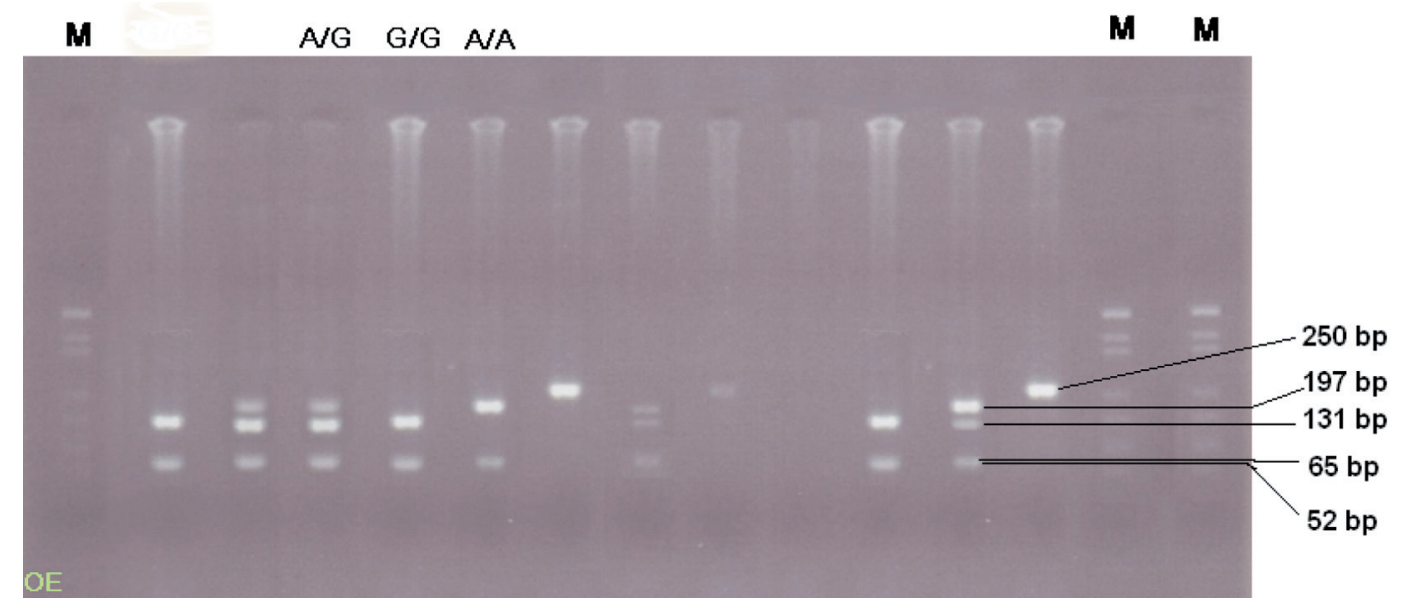

Figure 1. Restriction fragments. 
As an association study of a SNP in the SUR1 gene $(\mathrm{AGG} \rightarrow \mathrm{AGA}$; $\operatorname{Arg} 1273 \mathrm{Arg})$, the patients bearing at least one $\mathrm{A}$ allele $(\mathrm{AA}+\mathrm{AG} ; \mathrm{n}=54)$ had significantly higher triglyceride levels $(229 \pm 68$ vs. $186 \pm 59, \mathrm{P}<0.05)$, and had a higher frequency of family history of diabetes but the difference was not significant $(\mathrm{P}=0.13)$, than the patients without the A allele (GG; $\mathrm{n}=36)$. However, in patients with diabetes, there were no significant differences between different genotypes of the SUR1 gene polymorphism regarding fasting glucose, $\mathrm{HbA} 1 \mathrm{c}$, total cholesterol, disease duration, age of onset, presence of diabetic complications and oral anti-diabetic or insulin therapy (data not shown).

Table 1. Clinical and biochemical characteristics of the subjects.

\begin{tabular}{|c|c|c|c|c|}
\hline & Control group & Patients with $\mathrm{BMI}<25^{\mathrm{a}}$ & Patients with $\mathrm{BMI} \geq 30^{\mathrm{a}}$ & $\mathrm{p}$ \\
\hline Subjects $(n)$ & 80 & 45 & 45 & N.S. \\
\hline Age (years) & $56(45-70)$ & $55(43-68)$ & $57(44-70)$ & N.S. \\
\hline Sex (male-female) & $39-41$ & $22-23$ & $23-22$ & N.S. \\
\hline Length (m) & $1.65(1.55-1.80)$ & $1.66(1.56-1.78)$ & $1.62(1.50-1.82)$ & N.S. \\
\hline Weight (kg) & $69(58-83)$ & $60(52-75)$ & $88(68-115)$ & N.S. \\
\hline Family history (\%) & - & 49 & 62 & N.S. \\
\hline Duration of disease (years) & - & $9.2(1-18)$ & $11.4(2-22)$ & N.S. \\
\hline Age of diagnosis of disease (years) & - & $48(41-54)$ & $46(39-53)$ & N.S. \\
\hline Complicated patients (\%) & - & 35 & 42 & N.S. \\
\hline Treatment (Insulin \pm OAD-OAD) & - & $25 \%-75 \%$ & $38 \%-62 \%$ & N.S. \\
\hline Fasting glucose (mg/dl) & $88(69-112)$ & $158(118-255)$ & $185(123-314)$ & $<0.001$ \\
\hline $\mathrm{HbA} 1 \mathrm{c}(\%)$ & $5.2(4.1-6.6)$ & $8.8(5.6-13.3)$ & $9.7(5.9-14.2)$ & $<0.001$ \\
\hline Total cholesterol (mg/dl) & $170(125-232)$ & $182(128-265)$ & $235(170-298)$ & $<0.001$ \\
\hline Triglycerides (mg/dl) & $135(58-245)$ & $138(66-278)$ & 277 (145-383) & $<0.001$ \\
\hline
\end{tabular}

Data are expressed as mean and range; ${ }^{a}\left(\mathrm{~kg} / \mathrm{m}^{2}\right)$; BMI, body mass index; OAD, oral anti-diabetic agents.

Table 2. Genotypic and allelic distribution of exon 31 R1273R SNP of the SUR1 gene among type 2 DM patients and control subjects.

\begin{tabular}{lllll}
\hline & Controls $(n=80)$ & All patients $(n=90)$ & Patients with BMI<25 a $(n=45)$ & Patients with BMl $\geq 30^{\text {a }}(n=45)$ \\
\hline Genotypes & & & & \\
GG & $48(60 \%)$ & $36(40 \%)$ & $20(44 \%)$ & $16(36 \%)$ \\
GA & $26(32.5 \%)$ & $35(39 \%)$ & $17(38 \%)$ & $18(40 \%)$ \\
AA & $6(7.5 \%)$ & $19(21 \%)$ & $8(18 \%)$ & $11(24 \%)$ \\
P.value & & 0.01 & 0.12 & 0.007 \\
Alleles & & & & $50(56 \%)$ \\
G & $122(76 \%)$ & $107(59 \%)$ & $57(63 \%)$ & $40(44 \%)$ \\
A & $38(24 \%)$ & $73(41 \%)$ & $33(37 \%)$ & 0.001 \\
P.value & & 0.001 & 0.03 &
\end{tabular}

Data are expressed as number of subjects (percentage); ${ }^{a}\left(\mathrm{~kg} / \mathrm{m}^{2}\right) ; \mathrm{NS}$, no significant difference; $\mathrm{P}$ values as compared with control subjects. 


\section{DISCUSSION}

It has been shown that the pancreatic beta-cell KATP channel activity is impaired as a result of functional mutations of SUR1 or Kir6.2 subunits, leads to uncontrolled oversecretion of insulin despite severe hypoglycemia. ${ }^{13,14}$ Therefore, SUR1 and Kir6.2 genes have been suspected to be involved in the impaired insulin secretion in type $2 \mathrm{DM}$.

The mechanism of SUR1 polymorphism in hyperglycemia is revealed by studies on insulin secretion and insulin sensitivity in different genotypes. ${ }^{15,17}$ Our study reports that the SNP in exon 31 of the SUR1 gene is strongly associated with type $2 \mathrm{DM}$ in Turkish patients. This result favors previous studies and gives potent evidence for the role of SUR 1 gene in the etiology of the disease. We have observed an increased frequency of the A allele in exon 31 of the SUR1 gene in the case of type $2 \mathrm{DM}$, and it is noteworthy that this association was stronger in the subgroup of patients with obesity.

The relationship between SNPs of the SUR1 gene and type 2 DM has been demonstrated in many communities but different alleles or different SNPs were found to be related with type $2 \mathrm{DM}$ in each community. The SNPs in intron 15 splice acceptor site (IVS15-3c $\rightarrow$ t; cagGCC $\rightarrow \operatorname{tagGCC}$ ), exon 18 (ACC $\rightarrow$ ACT; Thr759Thr) and exon 31 $(\mathrm{AGG} \rightarrow \mathrm{AGA}$; Arg1273Arg) of the SUR1 gene have been found to be related with type $2 \mathrm{DM}$ in different populations. ${ }^{18,19}$ Despite these reports, it has been shown that SUR1 mutations impairing KATP channel activity do not appear to be major determinants of type 2 DM susceptibility in Japanese..$^{20}$ Allelic variation in the SUR1 gene plays a critical role in insulin secretion defect in type 2 DM etiology (Ashcroft et al., 1999). The A allele of a SNP in exon 31 of the SUR1 gene (AGG $\rightarrow$ AGA; Arg1273Arg) has previously been shown to be associated with hyperinsulinemia in nondiabetic Mexican-American subjects. ${ }^{11}$ This led to a study on probable SNPs on the same gene in French type 2 DM patients. In that study, as in ours, the A allele found to be associated with type $2 \mathrm{DM} .{ }^{12}$ The association reported in the same study was stronger in the subgroup of patients with age of diagnosis of diabetes equal to or less than 45 years. In this group of patients, allele and genotype frequencies were found to be similar in obese and nonobese subjects, while an association between the A allele and diabetes was observed only in nonobese subjects in the group of patients with age of diagnosis of diabetes in the second and third terciles of the distribution. Conversely, in our study, the association between the A allele and diabetes was stronger in obese type $2 \mathrm{DM}$ patients, which indicates the presence of multiple genes in the etiology and differences in environmental factors.

We also found that the patients bearing at least one A allele had significantly higher triglyceride levels, and had a higher frequency of family history of diabetes (not significant statistically) than the patients without the A allele. Type 2 DM and obesity are frequently associated and share metabolic abnormalities, and obesity, especially android-type of obesity is also found to be a risk factor for type 2 DM. $^{21,22}$ This phenotypic risk factor needs to be inspected genotypically. In addition, the hyperinsulinemia might result from an initial defect of the pancreatic beta-cell KATP channels and may contribute to the excess of fat deposition and to the development of insulin resistance. ${ }^{23,24}$ Taken together, these results suggest that the genes encoding key components of insulin secretion pathways can be considered as candidate genes not only for type 2 DM but also for obesity, and may point an intersection in the metabolic pathways. The possible effect of the SUR variants on obesity has not been evaluated clearly. Variations in the SUR genes could contribute to hyperglycemia and weight gain in individuals at high risk for obesity and type $2 \mathrm{DM}$. It has been reported that the exon $22 \mathrm{~T}$ variant of the SUR gene was associated with obesity and type 2 DM, and an indication of linkage between the SUR region and obesity was found in French Caucasians. ${ }^{8}$ These observations accentuate the importance of the complex interactions between obesity and type 2 DM. The genes encoding Kir6.2 and SUR1 subunits are located $4.5 \mathrm{~kb}$ apart on the human chromosome $11 \mathrm{p} 15.1 .{ }^{4}$ Moreover, it is noteworthy that the human chromosomal region $11 \mathrm{p} 15$ also harbors the human homolog of the tubby locus, which is responsible for hyperinsulinemia and severe obesity in mice. ${ }^{25}$ It has been also reported that the region on the short arm of chromosome 11 (11p15) shows suggestive evidence for linkage to obese type 2 diabetes, which also harbors the SUR1 gene. ${ }^{26,27}$ On the other hand, it is noteworthy that human adipocytes express SUR1 that regulates intracellular $\mathrm{Ca}^{+2}$ and, consequently, exerts coordinate control over lipogenesis and lipolysis, suggesting a potential role for 
the human adipocyte SUR1 in modulating energy storage and thereby potentially contributing to obesity. ${ }^{28}$

In our study, the patients with SNP in the SUR1 gene (AGG $\rightarrow$ AGA; Arg1273Arg) had significantly higher triglyceride levels than the patients without SNP, support the hypothesis that SUR1 has a potential role in mediating lipogenesis and lipolysis in the adipocytes. However, another study showed that SUR2B is expressed in human adipose tissue, whereas SUR1 was not detected. ${ }^{28}$ It seems to be that the SUR locus may contribute to genetic susceptibility to obesity-induced insulin resistance and type $2 \mathrm{DM}$, and this contribution is not only based on alteration in insulin secretion but also based on an extrapancreatic role of the SUR. In conclusion, we have observed that the SNP in exon 31 of the SUR1 gene is strongly associated with type 2 diabetes mellitus in Turkish patients with concomitant obesity.

Our findings and other reports indicate the complex interactions between type 2 DM and obesity. Variations in the SUR gene could contribute to fatty acid deposition, weight gain, and hyperglycemia and insulin resistance by alteration of insulin secretion and mediating lipogenesis and lipolysis in extrapancreatic tissues in individuals at high risk for type $2 \mathrm{DM}$ and obesity. The interactions of SUR variants with insulin secretion, insulin sensitivity, glucose tolerance, and especially with obesity are required to investigate properly in larger populations.

\section{Acknowledgments}

We wish to thank Tissue Typing and Genetic Laboratory of Ataturk University Aziziye Training Hospital for their expertise, and all volunteers.

\section{REFERENCES}

1. American Diabetes Association. Report of the expert committee on the diagnosis and classification of diabetes mellitus. Diabetes Care 1997; 20(7): 1183-97.

2. Ashcroft FM, Gribble FM. ATP-sensitive $\mathrm{K}+$ channels and insulin secretion: their role in health and disease. Diabetologia 1999; 42(8): 903-19.

3. Inagaki N, Gonoi T, Clement JP, et al. Reconstitution of IKATP: an inward rectifier subunit plus the sulfonylurea receptor. Science 1995; 270(5239): 1166-70.
4. Aguilar-Bryan L, Bryan J. Molecular biology of adenosine triphosphate-sensitive potassium channels. Endocrine Rev 1999; 20(2): 101-35.

5. Thomas PM, Wohllk N, Huang E, et al. Inactivation of the first nucleotide-binding fold of the sulfonylurea receptor, and familial persistent hyperinsulinemic hypoglycemia of infancy. Am J Hum Genet 1996; 59(3): 510-18.

6. DeFronzo RA. Pathogenesis of type 2 diabetes: metabolic and molecular implications for identifying diabetes genes. Diabetes Reviews 1997; 5(3): 177-85.

7. Velho G, Froguel P. Genetic determinants of non-insulindependent diabetes mellitus: strategies and recent results. Diabetes Metab 1997; 23(1): 7-17.

8. Hani EH, Clément K, Velho G, et al. Genetic studies of the sulfonylurea receptor gene locus in NIDDM and in morbid obesity among French Caucasians. Diabetes 1997; 46(4): 688-94.

9. Hansen T, Echwald SM, Hansen L, et al. Decreased tolbutamide-stimulated insulin secretion in healthy subjects with sequence variants in the high-affinity sulfonylurea receptor gene. Diabetes 1998; 47(4): 598-605.

10. Hart LM, de Knijff P, Dekker JM, et al. Variants in the sulphonylurea receptor gene: association of the exon 16-3t variant with Type II diabetes mellitus in Dutch Caucasians. Diabetologia 1999; 42(5): 617-20.

11. Goksel DL, Fischbach K, Duggirala R, et al. Variant in sulfonylurea receptor-1 gene is associated with high insulin concentrations in non-diabetic Mexican Americans: SUR-1 gene variant and hyperinsulinemia. Hum Genet 1998; 103(3): 280-5.

12. Reis AF, Ye WZ, Dubois-Laforgue D, Bellanne-Chantelot C, Timsit J, Velho G. Association of a variant in exon 31 of the sulfonylurea receptor 1 (SUR1) gene with type 2 diabetes mellitus in French Caucasians. Hum Genet 2000; 107(2): 138-44.

13. Thomas PM, Cote GJ, Hallman DM, Mathew PM. Homozygosity mapping, to chromosome $11 \mathrm{p}$, of the gene for familial persistent hyperinsulinemic hypoglycemia of infancy. Am J Hum Genet 1995; 56(2): 416-21.

14. Hamming KS, Soliman D, Matemisz LC, et al. Coexpression of the type 2 diabetes susceptibility gene variants KCNJ11 E23K and ABCC8 S1369A alter the ATP and sulfonylurea sensitivities of the ATP-sensitive $\mathrm{K}(+)$ channel. Diabetes 2009;58(10):2419-24.

15. Elbein SC, Sun J, Scroggin E, Teng K, Hasstedt SJ. Role of common sequence variants in insulin secretion in familial type 2 diabetic kindreds: the sulfonylurea receptor, glucokinase, and hepatocyte nuclear factor 1alpha genes. Diabetes Care 2001; 24(3): 472-8.

16. Hart LM, Dekker JM, Van Haeften TW, et al. Reduced second phase insulin secretion in carriers of a sulphonylurea receptor gene variant associating with Type II diabetes mellitus. Diabetologia 2000; 43(4): 515-9.

17. Weisnagel SJ, Rankinen T, Nadeau A, et al. Decreased fasting and oral glucose stimulated C-peptide in nondiabetic subjects with sequence variants in the sulfonylurea receptor 1 gene. Diabetes 2001; 50(3): 697-702. 
18. Inoue H, Ferrer J, Welling CM, et al. Sequence variants in the sulfonylurea receptor (SUR) gene are associated with NIDDM in Caucasians. Diabetes 1996; 45(6): 825-31.

19. Rissanen, J, Markkanen A, Karkkainen P, et al. Sulfonylurea receptor 1 gene variants are associated with gestational diabetes and type 2 diabetes but not with altered secretion of insulin. Diabetes Care 2000; 23(1): 70-3.

20. Ohta, Y, Tanizawa Y, Inoue H, et al. Identification and functional analysis of sulfonylurea receptor 1 variants in Japanese patients with NIDDM. Diabetes 1998; 47(3): 476-81.

21. Yki-Järvinen H. Pathogenesis of non-insulin dependent diabetes mellitus. Lancet 1994; 343(8889): 91-5.

22. Dworacka M, Winiarska H, Jagodziński PP. Impact of the sulfonylurea receptor 1 (SUR1) exon 16-3c/t polymorphism on acute hyperglycaemia in type 2 diabetic patients. Diabetes Res Clin Pract 2007;77(2):258-62.

23. O'Rahilly S, Gray H, Humphreys PJ, et al. Impaired processing of prohormones associated with abnormalities of glucose homeostasis and adrenal function. N Engl J Med 1995; 333(9): 1386-90
24. Yokoi N, Kanamori M, Horikawa Y, et al.Association studies of variants in the genes involved in pancreatic beta-cell function in type 2 diabetes in Japanese subjects. Diabetes $2006 ; 55(8): 2379-86$.

25. Jones JM, Meisler MH, Seldin MF, Lee BK, Eicher EM. Localization of insulin-2 (Ins-2) and the obesity mutant tubby (tub) to distinct regions of mouse chromosome 7 . Genomics 1992; 14(1): 197-9.

26. van Tilburg JH, Sandkuijl LA, Franke L, et al. Genomewide screen in obese pedigrees with type 2 diabetes mellitus from a defined Dutch population. Eur J Clin Invest 2003; 33(12): 1070-4.

27. Tarasov AI, Nicolson TJ, Riveline JP, et al. A rare mutation in ABCC8/SUR1 leading to altered ATP-sensitive $\mathrm{K}+$ channel activity and beta-cell glucose sensing is associated with type 2 diabetes in adults. Diabetes 2008;57(6):1595-604.

28. Shi H, Moustaid-Moussa N, Wilkison WO, Zemel MB. Role of the sulfonylurea receptor in regulating human adipocyte metabolism. FASEB J 1999; 13(13): 1833-8.

29. Gabrielsson BG, Karlsson AC, Lonn E, et al. Molecular characterization of a local sulfonylurea system in human adipose tissue. Mol Cell Biochem 2004; 258(1-2): 65-71. 